\title{
Evaluation of hematological parameters in oral cancer and oral pre-cancer
}

\author{
Shruti Singh $^{1}$, Jaya Singh ${ }^{1}$, Fahad Mansoor Samadi ${ }^{1 *}$, Shaleen Chandra ${ }^{1}$, \\ Roop Ganguly ${ }^{2}$, Shaista Suhail ${ }^{1}$
}

\begin{abstract}
${ }^{1}$ Department of Oral Pathology and Microbiology, King George's Medical University, Lucknow, Uttar Pradesh, India ${ }^{2}$ Department of Oral and Maxillofacial Surgery, King George's Medical University, Uttar Pradesh, India
\end{abstract}

Received: 04 April 2020

Revised: 14 May 2020

Accepted: 15 May 2020

\section{*Correspondence:}

Dr. Fahad Mansoor Samadi,

Email: oralpathresearch1@gmail.com

Copyright: (C) the author(s), publisher and licensee Medip Academy. This is an open-access article distributed under the terms of the Creative Commons Attribution Non-Commercial License, which permits unrestricted non-commercial use, distribution, and reproduction in any medium, provided the original work is properly cited.

\section{ABSTRACT}

Background: Oral squamous cell carcinoma (OSCC) is the most common public health issue in Indian population. Quite a large number of OSCC cases are preceded by potentially malignant disorders of oral cavity. The need for simple diagnostic marker for early diagnosis and thus better therapeutic outcome is imperative. The current study aims to evaluate hematological parameters such as hemoglobin, bleeding time, clotting time, total leucocyte count (TLC) and differential leucocyte count (DLC) in OSCC and oral potentially malignant disorder cases along with normal healthy controls.

Methods: A total of 150 subjects; 50 in each group were taken and $2.5 \mathrm{ml}$ of blood were withdrawn from each subject and TLC, DLC and hemoglobin assessment was done using autoanalyzer while bleeding time and clotting time was recorded through Duke's method and modified Dale's method respectively.

Results: All the data were tabulated and recorded as mean \pm standard deviation and comparison was done using oneway ANOVA test $(\mathrm{p}<0.05)$. TLC count, neutrophil count and lymphocyte count showed statistically significant difference amongst three groups while other parameters such as hemoglobin percentage, bleeding time, clotting time, eosinophil count, monocyte count and basophil count were statistically non-significant.

Conclusions: This study showed TLC count, neutrophil count and lymphocyte count might prove as useful determinant factor in oral squamous cell carcinoma and oral potentially malignant disorders. However, further study with larger sample size is required to establish their role as diagnostic, prognostic marker or predictor of malignant transformation.

Keywords: Bleeding time, Clotting time, Haemoglobin, Hematological, Differential leucocyte count, Oral potentially malignant disorders of oral cavity, Oral squamous cell carcinoma, Total leucocyte count

\section{INTRODUCTION}

Oral cancer reports for approximately $3 \%$ of all malignancies and affects $2,70,000$ patients annually worldwide. ${ }^{1}$ It is noteworthy that majority of the oral cancer derived from oral precancerous lesions such as leukoplakia, oral submucous fibrosis, amongst others. ${ }^{1}$ Oral pre-cancer lesions have quite high malignant transformation rate. ${ }^{2}$ Numerous biomarkers are have been studied in order to provide early diagnosis and treatment, thus better survival rate of the patients. ${ }^{3}$ Many attempts have been done on blood biochemistry and hematology to explore the etiology of cancers and to establish this as tumor markers. Quantitative alteration in the serum during tumor initiation and progression takes place. Thus, authors aim to study the haematological 
profile in oral squamous cell carcinoma and oral precancer cases.

\section{METHODS}

The study took place in the hematology unit of Department of Oral Pathology and Microbiology, King George's Medical University from the period of January 2019 till December 2019. Institutional ethical clearance and informed consent from the patients were duly obtained. A total of 150 subjects participated in the study. The subjects were divided into three groups.

Group I involve 50 subjects with clinical and histopathologically confirmed cases of oral cancer. Group II consists 50 subjects with clinical and histopathologically confirmed cases of oral pre-cancer (includes oral leukoplakia, erythroplakia, oral lichen planus and oral submucous fibrosis) and Group III includes 50 subjects of normal healthy control.

\section{Inclusion criteria}

Subjects within age range of 20-70 years, only clinically and histopathologically confirmed cases of oral cancers cases, only clinically confirmed cases of oral leukoplakia, erythroplakia, oral submucous fibrosis, oral lichen planus and histopathologically confirmed having oral epithelial dysplasia were included in the study.

\section{Exclusion criteria}

Patients suffering with chronic diseases such as diabetes, hypertension, renal, cardiac or hepatic disease, subjects with periodontitis, subjects with history of bleeding or clotting disorders such as hemophilia etc., subjects with previous history of malignancy or has undergone any cancer treatment, patients having malignancy at any other site other than oral cancer were excluded from the study.

A total $2.5 \mathrm{ml}$ of blood was drawn from the patient in a vial and hematological parameters were assessed using Erba-Transasia B7256 autoanalyzer. The bleeding time was carried out by the Duke's method wherein a standard deep cut was made on the finger pulp with a lancet of 3 $\mathrm{mm}$ depth, the first drop of blood was wiped out subsequently the blood was blotted on a filter paper every 30 sec until the blood stopped oozing. The normal bleeding time by this method is $1-5$ minutes. ${ }^{4}$ The whole blood clotting time was carried out by modified Dale's method wherein the similar prick is made into the finger pulp and blood is taken into a standard glass capillary tube by the capillary action. Subsequent to this the end of capillary tube is broken every $30 \mathrm{sec}$ until the clot is formed and the end of capillary tube starts hanging. The normal clotting time by this method is $5-11$ minutes. ${ }^{4}$

All the data were tabulated and mean value with standard deviation were calculated (Table 1). The data were analysed by using SPSS (statistical package for software solutions) version- 18 software (IBM Inc. NY, USA) The comparison between the three groups was calculated using one-way ANOVA test $(\mathrm{p} \leq 0.05)$ (Table 2$)$.

\section{RESULTS}

The mean age in oral cancer group were $50.92 \pm 15.192$ years; in potentially malignant disorders of oral cavity were $45.08 \pm 14.241$ years while in the control group were $38.00 \pm 14.842$ years (Table 1$)$. There were $76 \%$ males and $24 \%$ females in group 1; $74 \%$ males and $26 \%$ females in group 2 and there were $50 \%$ males and $50 \%$ females in the control group (Figure1).

Table 1: Mean data along with standard deviations of all the variables.

\begin{tabular}{|c|c|c|c|c|c|c|c|c|c|}
\hline \multirow{2}{*}{ Parameters } & \multicolumn{2}{|c|}{ Group $1(n=50)$} & \multicolumn{2}{|c|}{ Group $2(n=50)$} & \multicolumn{2}{|c|}{ Group 3 (n=50) } & \multicolumn{2}{|c|}{ Total $(n=150)$} & \multirow[t]{2}{*}{ P value } \\
\hline & Mean & SD & Mean & SD & Mean & SD & Mean & SD & \\
\hline Age in years & 50.92 & 15.192 & 45.08 & 14.241 & 38.00 & 14.842 & 44.37 & 15.601 & 0.000 \\
\hline Hb (\%) & 12.9531 & 1.67445 & 13.0348 & 2.31935 & 12.8855 & 1.62895 & 12.9555 & 1.88223 & 0.922 \\
\hline BT (min) & 2.2622 & 0.14344 & 2.3536 & 0.26664 & 2.2745 & 0.23938 & 2.2963 & 0.22597 & 0.088 \\
\hline CT (min) & 4.3990 & 0.26838 & 4.4856 & 0.32033 & 4.3936 & 0.21 & 4.4252 & 0.27 & 0.157 \\
\hline TLC $\left(10^{9} / \mathrm{l}\right)$ & 8087.755 & 2412.435 & 8164.000 & 2586.523 & 6903.636 & 1650.248 & 7689.610 & 2296.947 & $0.006^{*}$ \\
\hline $\mathbf{N}\left(\right.$ cells $\left./ \mathbf{m m}^{3}\right)$ & 63.9184 & 10.43998 & 62.9600 & 8.87317 & 58.5091 & 9.36280 & 61.6753 & 9.80322 & $0.009 *$ \\
\hline & 24.6122 & 9.72072 & 26.2000 & 7.57008 & 30.3818 & 7.98956 & 27.1883 & 8.75429 & $0.002 *$ \\
\hline E (cells/ $\mu \mathrm{l})$ & 7.7755 & 4.26842 & 7.5800 & 2.46684 & 7.4727 & 3.19058 & 7.6039 & 3.35760 & 0.900 \\
\hline M (cells/ $/ \mu \mathrm{l})$ & 3.6122 & 2.02912 & 3.3400 & 1.30321 & 3.6000 & 1.62845 & 3.5195 & 1.66949 & 0.654 \\
\hline B $($ cells/ $\mu \mathrm{l})$ & 0.0000 & 0.00000 & 0.0000 & 0.00000 & 0.0000 & 0.00000 & 0.0000 & 0.00000 & 0.00000 \\
\hline
\end{tabular}

Hb- Haemoglobin, BT- Bleeding time, CT- Clotting time, TLC- Total leucocyte count, N- Neutrophils, L- Lymphocytes, E- Eosinophils, M- Monocyte, B- Basophils. 


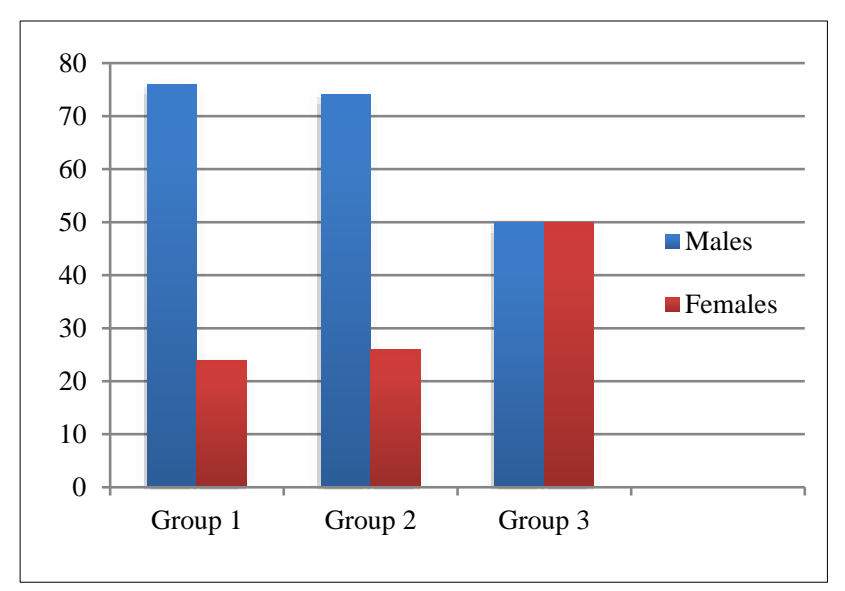

Figure 1: Gender distribution among three groups.

The mean hemoglobin in group 1 was 12.9531 1.67445 ; in group 2 was $13.0348 \pm 2.31935$ and group 3 was $12.8855 \pm 1.62895$. The mean bleeding time in oral cancer subjects was $2.2622 \pm 0.14344$ in oral pre-cancer subjects was 2.3536 \pm 0.26664 and in control subjects was $2.2745 \pm 0.23938$. The mean clotting time in group I was
$4.3990 \pm 0.26838$; in group 2 was $4.4856 \pm 0.32033$ and in group 3 was $4.3936 \pm 0.211$. The means TLC count in group $1,8087.75 \pm 2412.43$; in group 2 was $8164 \pm 2585.52$ while in control group is $6903.63 \pm 1650.24843$. The mean neutrophil count in group 1 was $63.918 \pm 10.439$, in group 2 was $62.960 \pm 8.8731$ while in group 3 was $58.509 \pm 9.3628$. The mean lymphocyte count in group 1 was 24.612 \pm 9.7207 ; in group 2 was $26.200 \pm 7.5700$ and in group 3 was $30.381 \pm 7.98956$. The mean eosinophil count in cancer subject was $7.7755 \pm 4.26842$; in oral pre-cancer subject was $7.5800 \pm 2.4668$ and in normal healthy control 7.6039 \pm 3.3576 . The mean monocyte count was $3.6122 \pm 2.0291$ in oral cancer subjects; $3.3400 \pm 1.3032$ in oral precancer subjects and $3.600 \pm 1.6284$ in normal healthy controls. The mean basophil count in all the three groups of oral cancer, oral pre-cancer and normal healthy control was $0.000 \pm 0.000$ (Table 1 ).

The mean TLC count, neutrophil count and the lymphocyte count between the three groups were statistically significant. The other parameters when compared were found to be statistically non-significant. (Table 1 and 2).

Table 2: Comparison of different parameters between groups using one-way ANOVA test.

\begin{tabular}{|c|c|c|c|c|c|c|}
\hline \multicolumn{2}{|l|}{ Variables } & Sum of squares & df & Mean square & $\mathbf{F}$ & P value \\
\hline \multirow{3}{*}{ Age in years } & Between groups & 4314.157 & 2 & 2157.078 & \multirow[t]{3}{*}{9.901} & \multirow[t]{3}{*}{0.000} \\
\hline & Within groups & 32681.347 & 150 & 217.876 & & \\
\hline & Total & 36995.503 & 152 & & & \\
\hline \multirow{3}{*}{$\mathbf{H b}(\%)$} & Between groups & 0.585 & 2 & 0.292 & \multirow[t]{3}{*}{0.082} & \multirow[t]{3}{*}{0.922} \\
\hline & Within groups & 541.461 & 151 & 3.586 & & \\
\hline & Total & 542.045 & 153 & & & \\
\hline \multirow[t]{3}{*}{ BT (min) } & Between groups & 0.247 & 2 & 0.124 & \multirow[t]{3}{*}{2.465} & \multirow[t]{3}{*}{0.088} \\
\hline & Within groups & 7.566 & 151 & 0.050 & & \\
\hline & Total & 7.813 & 153 & & & \\
\hline \multirow[t]{3}{*}{ CT (min) } & Between groups & 0.271 & 2 & 0.135 & \multirow[t]{3}{*}{1.877} & \multirow[t]{3}{*}{0.157} \\
\hline & Within groups & 10.896 & 151 & 0.072 & & \\
\hline & Total & 11.166 & 153 & & & \\
\hline \multirow[t]{3}{*}{ TLC $\left(10^{9} / I\right)$} & Between groups & $5.300 \mathrm{E} 7$ & 2 & $2.650 \mathrm{E} 7$ & \multirow[t]{3}{*}{5.305} & \multirow[t]{3}{*}{0.006} \\
\hline & Within groups & $7.542 \mathrm{E} 8$ & 151 & 4994881.628 & & \\
\hline & Total & 8.072E8 & 153 & & & \\
\hline \multirow{3}{*}{$\begin{array}{l}\mathbf{N} \\
\left(\text { cells/mm } \mathbf{m m}^{3}\right)\end{array}$} & Between groups & 880.427 & 2 & 440.214 & \multirow[t]{3}{*}{4.809} & \multirow[t]{3}{*}{0.009} \\
\hline & Within groups & 13823.339 & 151 & 91.545 & & \\
\hline & Total & 14703.766 & 153 & & & \\
\hline \multirow{3}{*}{$\mathbf{L}($ cells $/ \boldsymbol{\mu l})$} & Between groups & 934.924 & 2 & 467.462 & \multirow[t]{3}{*}{6.541} & \multirow[t]{3}{*}{0.002} \\
\hline & Within groups & 10790.614 & 151 & 71.461 & & \\
\hline & Total & 11725.539 & 153 & & & \\
\hline \multirow[t]{3}{*}{ E $($ cells $/ \mu \mathrm{l})$} & Between groups & 2.418 & 2 & 1.209 & \multirow[t]{3}{*}{0.106} & \multirow[t]{3}{*}{0.900} \\
\hline & Within groups & 1722.420 & 151 & 11.407 & & \\
\hline & Total & 1724.838 & 153 & & & \\
\hline \multirow[t]{3}{*}{ M $($ cells $/ \mu \mathrm{l})$} & Between groups & 2.389 & 2 & 1.194 & \multirow[t]{3}{*}{0.425} & \multirow[t]{3}{*}{0.654} \\
\hline & Within groups & 424.053 & 151 & 2.808 & & \\
\hline & Total & 426.442 & 153 & & & \\
\hline \multirow[t]{3}{*}{ B $($ cells $/ \mu \mathrm{l})$} & Between groups & 0.000 & 2 & 0.000 & & \\
\hline & Within groups & 0.000 & 151 & 0.000 & & \\
\hline & Total & 0.000 & 153 & & & \\
\hline
\end{tabular}

Hb- Haemoglobin, BT- Bleeding time, CT- Clotting time, TLC- Total leucocyte count, N- Neutrophils, L- Lymphocytes, E- Eosinophils, M- Monocyte, B- Basophils. 


\section{DISCUSSION}

The prevalence of oral cancer is highest in India as per the World Oral Health Report 2003. Oral cancer ranks number one amongst men and number three amongst women in India. Oral cancer constitutes $12 \%$ of all cancers in men and $8 \%$ of all cancers among women. ${ }^{5}$ The presence of epithelial dysplasia is considered to play a pivotal role in malignant transformation. ${ }^{6}$ The quest for a definite biomarker in oral cancer and oral pre-cancerous lesions for early diagnosis and thus better therapeutic outcome in different biological media including blood, saliva and urine are is still on. ${ }^{7-9}$ The current study aim to compare and evaluate total leucocyte count, differential leucocyte count, bleeding time and clotting time in oral precancerous and oral cancer lesions.

Inflammation plays a critical role in tumorigenesis. ${ }^{10}$ It plays an elemental role in tumor initiation, progression and metastasis and also in conversion from potentially malignant lesion to full blown malignancy. ${ }^{11}$ Systemic Inflammatory response are being evaluated as one of key biomarker in oral cancer. It has been suggested that Systemic inflammatory response may be the effect of the tumor hypoxia or necrosis or the consequence of the local tissue injury. ${ }^{12}$ The most used biomarkers that reflect a systemic inflammatory response are white blood cell subtypes. ${ }^{13}$ White blood cell count is highly variable because it is responsive to diverse acute and chronic stimuli. It is increased in infection, stress and smoking. ${ }^{13}$ The stromal tissue of tumors has high WBC count and inflammatory cells and their cytokine production seems to co-relate with tumour severity. ${ }^{14}$

Tsai et al in his study on oral cavity cancer, showed that the peripheral total white blood cell (WBC) count, monocyte, and neutrophil counts and neutrophil lymphocyte ratio increased with the stage T4 and poor tumour differentiation. ${ }^{15}$ Kuss L et al, found altered lymphocyte homeostasis in head and neck squamous cell carcinoma cases, which persisted for months, or years after curative therapies. ${ }^{16}$ Grim et al reported that WBC count was associated with risk of cancer death. ${ }^{17}$ Erlinger et al postulated WBC count with cancer mortality. ${ }^{18}$ Shankar et al also found an association between high WBC count and cancer mortality. ${ }^{19}$ The evidence seems to be increasing that, cellular proliferation in an environment rich in, inflammatory cells, growth factors and activated stroma is associated with DNA damage that can potentiate the growth of cancer cells. ${ }^{20}$

Despite the evident link in coagulation cascade and cancer in the literature, this study showed no significant difference in bleeding time and clotting time between oral pre-cancer, oral cancer and normal controls. ${ }^{21}$ Still, further studies with more specific parameters are needed to conclude to the relationship between hemostatsis, coagulation cascade and oral cancer and oral pre-cancer lesions.
The correlation between hemoglobin status and head and neck cancer or potentially malignant lesion of oral cavity is still unclear. Studies suggested that pre-chemoradiation hemoglobin level to be an important determinant of outcome in carcinoma esophagus. ${ }^{22}$ For other risk factors, such as p53 mutation, loss of heterozygosity (LOH), HPV, etc. ${ }^{23}$ Claudia Cordilla in the study revealed hemoglobin status is associated with lymph node metastasis in squamous cell carcinoma of oral cavity but not with initial $\mathrm{T}$ stage. ${ }^{24}$ Also, contrary to this study finding, Bhattacharjee et al showed statistically significant difference in hemoglobin value between squamous cell carcinoma of oral cavity and epithelial precursor lesion with the control. ${ }^{22}$

\section{CONCLUSION}

This study showed statistically significant difference between total leucocyte count, neutrophil count and lymphocyte count but other parameters such as hemoglobin status, basophil count, monocyte count, eosinophil count, bleeding time and clotting time showed no such difference. There are various confounding factors, which also influence the variation in hematological parameters. Still further studies with larger sample size and with more precise study design is needed.

Funding: No funding sources

Conflict of interest: None declared

Ethical approval: The study was approved by the Institutional Ethics Committee

\section{REFERENCES}

1. Mortazavi H, Baharvand M, Mehdipour M. Oral Potentially Malignant Disorders: An overview of more than 20 entities. J Dent Res Clin Dent Prospects.2014;8(1):6-14.

2. Warnakulasuriya S. Causes of oral cancer-an appraisal of controversies. Br Dent J. 2009;207:4715.

3. Parakh MK, Ulaganambi S, Ashifa N, Premkumar R, Jain AL. Oral potentially malignant disorders: clinical diagnosis and current screening aids: a narrative review. Eur J Cancer Prev. 2020;29(1):6572.

4. Bharadwaj JR. Laboratory investigation of hemolytic and purpuric disorders. In: Laboratory Manual of the Armed Forces; 2001;1:41-54.

5. Sankaranarayanan R. Oral cancer in India: an epidemiologic and clinical review. Oral Surg Oral Med Oral Pathol. 1990;69(3):325-30.

6. Nagao $\mathrm{T}$, Ikeda $\mathrm{N}$, Fukano $\mathrm{H}$, Hashimoto $\mathrm{S}$, Shimozato K, Warnakulasuriya S. Incidence rates for oral leukoplakia and lichen planus in a Japanese population. J Oral Pathol Med. 2005;34(9):532-9.

7. Fernández-Olavarría A, Mosquera-Pérez R, DíazSánchez RM, Serrera-Figallo MA, Gutiérrez-Pérez JL, Torres-Lagares D. The role of serum biomarkers in the diagnosis and prognosis of oral cancer: A 
systematic review. J Clin Exp Dent. 2016;8(2):18493.

8. Khurshid Z, Zafar MS, Khan RS, Najeeb S, Slowey PD, Rehman IU. Role of salivary biomarkers in oral cancer detection. Adv Clin Chem. 2018;86:23-70.

9. Patel JB, Shukla SN, Patel HR, Kothari KK, Shah PM, Patel PS. Utility of urinary biomarkers in oral cancer. Asian Pac J Cancer Prev. 2007;8(2):229-35.

10. Karin M. Nuclear factor-kappaB in cancer development and progression. Nature. 2006;441:4316.

11. Grivennikov SI, Greten FR, Michael K. Immunity, inflammation, and cancer. Cell. 2010;140(6):883-99.

12. Tampa M, Mitran MI, Mitran CJ, Sarbu MI, Matei C, Nicolae I, et al. Mediators of inflammation - a potential source of biomarkers in oral squamous cell carcinoma. Hindawi. J Immunol Res. 2018;1061780:1-12.

13. Jee SH, Park JY, Kim HS, Lee TY, Samet JM. White blood cell count and risk for all-cause, cardiovascular, and cancer mortality in a cohort of Koreans. Am J Epidemiol. 2005;162:1062-9.

14. Balkwill F. Cancer and the chemokine network. Nat Rev Cancer. 2004;4:540-50.

15. Tsai YD, Wang CP, Chen CY. Pretreatment circulating monocyte count associated with poor prognosis in patients with oral cavity cancer. Head Neck. 2014;36(7):947-53.

16. Kuss I, Hathaway B, Ferris RL, Gooding W, Whiteside TL. Imbalance in absolute counts of $\mathrm{T}$ lymphocyte subsets in patients with head and neck cancer and its relation to disease. Adv Otorhinolaryngol. 2005;62:161-72.

17. Grimm RH, Neaton JD, Ludwig W. Prognostic importance of the white blood cell count for coronary, cancer, and all-cause mortality. JAMA. 1985;254(14):1932-7.

18. Erlinger TP, Muntner P, Helzlsouer KJ. WBC count and the risk of cancer mortality in a national sample of U.S. adults: results from the Second National Health and Nutrition Examination Survey mortality study. Cancer Epidemiol Biomarkers Prev. 2004;13(6):1052-6.

19. Shankar A, Mitchell P, Rochtchina E, Tan J, Wang JJ. Association between circulating white blood cell count and long-term incidence of age-related macular degeneration: the blue mountains eye study. Am J Epidemiol. 2007;165(4):375-82.

20. Narang D, Shishodiya S, Sur J, Khan NF. White blood cells count: as a pathological diagnostic marker for oral pre-cancerous lesions and conditions: a randomized blind trial. $\mathrm{J}$ Carcinog Mutagen. 2014;5:188.

21. Lyman GH, Khorana AA. Cancer, clots and consensus: new understanding of an old problem. J Clin Oncol. 2009;27(29):4821-6.

22. Hefler L, Mayerhofer K, Leibman B, Obermair A, Reinthaller A, Kainz C, Tempfer C. Tumor anemia and thrombocytosis in patients with vulvar cancer. Tumour Biol. 2000;21:309-14.

23. Bhattacharjee A, Borah FR, Sarbani G, Devnath B, Uddin S. Evaluation of hematological parameters as a possible marker for head-and-neck cancer and precancerous conditions. J Evolut Med Dent Sci. 2015;4(95):1611-7.

24. Cordella C, Luebbers HT, Rivelli V, Grätz KW, Kruse AL. An evaluation of the preoperative hemoglobin level as a prognostic factor for oral squamous cell carcinoma. Head Neck Oncol. 2011;3:35.

Cite this article as: Singh S, Singh J, Samadi FM, Chandra S, Ganguly R, Suhail S. Evaluation of hematological parameters in oral cancer and oral precancer. Int J Basic Clin Pharmacol 2020;9:1090-4. 